\title{
Comparative Chemical Constituents of some Cassia Species and their Pharmacognistic Importance in South Eastern Nigeria
}

\author{
Awomukwu, Daniel Azubuike ${ }^{1, ~ *, ~ N y a n a n y o, ~ B i o ~ L o u i s ² ~}{ }^{2}$ Ikpeama, Ahamefule Ifeanyichukwu ${ }^{3}$, \\ Adieze, Charles Ugochukwu ${ }^{4}$ \\ ${ }^{1}$ Department of Biological Sciences, Federal University, Otuoke, Bayelsa State, Nigeria \\ ${ }^{2}$ Department of Plant Science and Biotechnology, University of Port Harcourt, Port Harcourt, Rivers State, Nigeria \\ ${ }^{3}$ National Root Crop Research Institute, Umuahia, Abia State, Nigeria \\ ${ }^{4}$ Department of Biology Microbiology, Abia State Polytechnic, Aba, Abia State, Nigeria

\section{Email address:} \\ xdanny18@yahoo.com (Awomukwu, D. A.), bionyananyo@yahoo.com (Nyananyo, B. L.), ahamson2003@yahoo.com (Ikpeama, A. I.), \\ charlesadiezeh@yahoo.com (Adieze, C. U.)
}

\section{To cite this article:}

Awomukwu, Daniel Azubuike, Nyananyo, Bio Louis, Ikpeama, Ahamefule Ifeanyichukwu, Adieze, Charles Ugochukwu. Comparative Chemical Constituents of some Cassia Species and their Pharmacognistic Importance in South Eastern Nigeria. Science Journal of Chemistry. Vol. 3, No. 3, 2015, pp. 40-49. doi: 10.11648/j.sjc.20150303.12

\begin{abstract}
An assessment and investigation into three species of Cassia namely Cassia alata Linn., Cassia occidentalis Linn. and Cassia sieberiana DC. belonging to the family of Fabaceae (subfamily Caesalpinoideae) was carried out with the aim of identifying and quantifying the bioactive components of these ornamental shrubs. The alkaloid, flavonoid, saponin, steroid, phenol and tannin contents of the vegetative and reproductive parts of these plants viz. the leaves, stems, roots and pods were screened and compared. All the plant parts investigated contained appreciable amount of alkaloids, flavonoids and saponins ranging from $(1.24 \pm 0.06 \%-4.06 \pm 0.51 \%),(1.18 \pm 0.0 \%-2.68 \pm 0 \%)$ and $(2.20 \pm 0.03 \%-4.28 \pm 0 \%)$ respectively. Tannin contents on the plant parts were equally high $(1.12 \pm 0.01 \%-1.54 \pm 0.01 \%)$, while the phenol contents ranged from $(0.13 \pm 0 \%-0.36 \pm 0 \%)$ respectively. These analytical results suggest the plants have a significant role in phyto-medicine. The importance of these plants was discussed in line with the role they play in ethno-medicinal life of the people.
\end{abstract}

Keywords: Cassia Species, Phytochemical Constituents, Medicinal Properties

\section{Introduction}

The genus "Cassia" is a member of the Fabaceae family (Leguminosae family) in the major group angiosperms (flowering plants). The Fabaceae or Leguminosae, commonly known as the legume, pea or bean family, is a large and economic important family of flowering plants. Plants of this family are found throughout the world, growing in many different environments and climates (Stevens, 2001).The plants range in habit from giant trees to small annual herbs, with the majority being herbaceous perennials. The plants have indeterminate inflorescences, which are sometimes reduced to a single flower. The flowers have a short hypanthium and a single carpel with a short gynophore, and after fertilization produce fruits that are legumes (Schrire et al., 2005). The leaves are usually alternate compound, and are even - or odd-pinnately compound. The name "Cassia" means "Cinnamon-like bark". In addition, the genus Cassia was for long illdelimited with regards to the related Cassiinae - especially Senna (which has many medicinal important species). (Frodin, 2004).

The medicinal value of these plants lies on some chemical substances that produces a definite physiological effect of these substances are, alkaloids, flavonoids, glycosides, tannin oils, phenols and many others (Omaye, 2004). According to Kapur and Atal (1982), there is need that the local herbs be evaluated for phytochemistry so as to 
determine the potential of indigenous sources of medicines.Many plants in this genus are used extensively in traditional medicine in tropical and warm subs tropical countries (Robber and Speedie, 1996). It is believed to possess a laxative effect. Its extract is reported to be beneficial in treating many skin diseases like eczema, rashes, ringworm etc, the seeds are roasted and boiled in water to produce tea as folk medicine (Perry, 1980). These plants have also been reported to treat constipation, common cold, fevers, intestinal disorders and in healing of wounds (Burkill, 1995).

The importance of medicinal plants has been elucidated by Edeoga et al. $(2003,2005)$ and their importance in the pharmaceutical industry. These medicinal plants have been underutilized in orthodox medicine but have confirmed to be used worldwide in the pharmaceutical, food, cosmetics and perfume industries (Robber and Speedie, 1996).

Alkaloids are very important in medicine and constitute most of the valuable drugs. They have marked physiological effect on animals (Edeoga and Eriata, 2001) and show considerable pharmaceutical activity (Davis and Heywood, 1963). Alkaloids are stimulants acts and by prolonging actions of several hormones which require phosphodiestrerase (Chukwu, 2000) though are poisonous to cattle (Holm et al., 1997).

Tannins are useful in medicine because of their astringent properties. Tannins and Alkaloids are known to have antiherbivore defense functions in plants (Harborne, 1988). Thus, the presence of tannins and alkaloids in medicinal plants could be serving as a deterrent to grazers (Edeoga and Eriata, 2001). Herbs that contain tannins are recommended for a wide range of treatments including inflammation, liver injury, kidney problems, arteriosclerosis, hypertension, stomach problems and inhibition of active oxygen and are commonly recommended as diuretics, antidiarrheas and haemostatic (Zhu et al., 1997)

Saponins are glycosides widely occurring in a variety of plants and are characterized by their bitter taste and foaming in aqueous solution. They prevent disease invasion of plants by parasitic fungi (Igile et al., 1994). Steroidal saponins from various studies indicate their importance and the interest in pharmacy due to their relationship with such compounds such as sex hormones especially in development of the female contraceptive pills (Okwu, 2003). In medicine, it is used to some extent as an expectorant and emulsifying agent (Edeoga and Ikem, 2001).
Flavonoids are the commonest phenolic constituents having 15-compounds generally distributed throughout the plants kingdom (Harborne, 1988). Some flavonoids have antibacterial function with gram-positive species more sensitive to isoflavanones, than their negative counterpart. Flavours are related to flavonoids and they promote particular tastes to prepared foods. The presence of flavonoids in plants have shown some effects like antibacterial, antiviral, antitoxin, antioxidant, antiinflammatory anti-carcinogenic activities (Huang and Ferraro, 1992). Isoflavanones, isoflavans, isoflavonones are extremely fungal pathogens (Dakoro, 1995). They act as allelochemicals widely used in insecticides and in treatment certain physiological disorders and disease control.

Phenols are synthesized via the shikimic acids pathway. Phenolic compounds are known to have anti-fungal and anti-microbial effects. Phenolic compounds believe to be active ingredients in the herbicide found up as well as some other commercial herbicide formulation (Heyde, 1990).

The acceptance of traditional medicine as an alternative form of health care hassled researchers to further investigate the antimicrobial and other health benefits of these medicinal plants. Medicinal plants are the richest bioresources of drugs of traditional systems of medicine, modern medicine, nutraceuticals, food supplements, folk medicines, pharmaceutical intermediates and chemical entities for synthetic drugs. Extracting the relatively complex mixtures of metabolites is achieved by using selective solvents. During extraction, solvents diffuse into the solid plant material and solubilize compounds with similar polarity (Afolayan et al., 2008).

\section{Materials and Methods}

\subsection{Collection of Plant Materials}

Mature plants of the three species, $C$. alata, $C$. occidentalis and $C$. sieberiana were collected from different locations of South Eastern Nigeria by various investigators as in Table 1. Only healthy, fresh and succulent parts of the plants were collected. The three specimens were identified and authenticated at the Herbarium of the Department of Plant Science and Biotechnology, Michael Okpara University of Agriculture, Umudike. Herbarium specimens were also studied at the various institutions as well making reference to the Flora of West Tropical Africa by Hutchinson and Dalziel (1963).

Table 1. Collection sites of the three Cassia species studied.

\begin{tabular}{ll}
\hline Species & Sites of collection \\
\hline Cassia alata & The Botanical Garden, Abia State Polytechnic, Aba, Abia State. \\
Cassia occidentalis & Forestry Research Department, M.O.U.A,Umudike, Umuahia, Abia State. \\
Cassia sieberiana & Science Village, Nnamdi Azikiwe University, Awka, Anambra State. \\
\hline
\end{tabular}


Table 2. Ethnobotanical uses of the studied Cassia species around the world.

\begin{tabular}{|c|c|c|}
\hline Species & Location & Ailment \& Treatment/ Properties and Action \\
\hline \multirow[t]{6}{*}{ Cassia alata } & Asia & Laxative properties, Constipation, Intestinal worm expeller, Eczema, Ringworm. \\
\hline & Congo Brazzaville & $\begin{array}{l}\text { Child delivery, Cough, Mouthwash, Stomatitis, Bronchitis, Expectorant, Astringent properties, Fungicide } \\
\text { properties. }\end{array}$ \\
\hline & India & Expectorant in bronchitis and dyspnoea. \\
\hline & China & Diuresis, Sudorific. \\
\hline & South America & $\begin{array}{l}\text { Tympanites for poisonous bites, Stomach pain, Dysentery, Hemorrhoids, Schistomiasis, Gonorrhea, } \\
\text { Convulsion, Heart failure, Oedema, Jaundice, Headache, Hernia, Paralysis. }\end{array}$ \\
\hline & Cote d'Ivoire & Liver problems, Urticaria rhinitis, Loss of appetite. \\
\hline \multicolumn{3}{|c|}{ Sources: Ajose, 2005; Arbonnier, 2004; Elujoba et al., 1989; Gill, 1992; Idu et al., 2006; Palanichamy and Nagaraj, 1990; Ross, 2003.} \\
\hline Species & Location & Ailment \& Treatment/ Properties and Action \\
\hline \multirow[t]{8}{*}{ Cassia occidentalis } & Panama & Stomach-ache, Dyspepsia, Flatulence, Constipation. \\
\hline & India & Dyspepsia, Flatulence, Constipation, Hic-cough, Hepatitis, Liver cirrhosis, Whooping cough, Diuresis. \\
\hline & Peru and Brazil & Fortify liver,Diuresis. \\
\hline & Benin Republic & Hepatitis, Jaundice, Fever, Cough, Asthma. \\
\hline & Suriname & Sore-throat, Cold, Flu, Asthma, Diuresis, Hypertension. \\
\hline & Garbon\& Guinea & Diuresis \\
\hline & Congo & Ease of child delivery. \\
\hline & Senegal & Female fertility. \\
\hline \multicolumn{3}{|c|}{ Sources: Neuwinger, 1996; Panda, 2004; Warrier, 1994.} \\
\hline Species & Location & Ailment \& Treatment/ Properties and Action \\
\hline \multirow{5}{*}{ Cassia sieberiana } & Senegal & Purgative, Diuresis, Malaria, Stomach ache, Ulcer, Diarrhea, Gonorrhea. \\
\hline & Uganda & Toothache, Skin diseases, Diarrhoea, Dysentery, Vomiting. \\
\hline & Cote d'Ivoire & Intestinal worm expeller, Venereal diseases, Sterility, Dysmenorrhea, Aphrodisia, Fish poison. \\
\hline & Burkina Faso & Malaria, Laxative. \\
\hline & Benin Republic & Sleeping sickness, Hemorrhoids, Bilharzia, Leprosy, Dropsy, Blood dysentery. \\
\hline
\end{tabular}

\subsection{Preparation and Analysis}

The plant materials were air-dried and milled into uniform powder using Thomas-Willey milling machine. The aqueous extract of each sample was determined by soaking $50 \mathrm{~g}$ of dried powdered sample in $10 \mathrm{ml}$ of distilled water for 12 hours The mixtures were filtered using Whatman filter paper and excess water removed by concentration by boiling the extract to $100^{\circ} \mathrm{C}$ for 10 minutes.

\subsection{Phytochemical Determination}

\subsubsection{QualitativeDetermination of the Chemical Constituents}

Freshly prepared ground samples are chemically tested for the presence of chemical constituents using standard procedures (Trease and Evans, 1989). Water or ethanol extracts are commonly used.

\section{(i). Test for Alkaloids}

One $\mathrm{mL}$ of extract of the sample was shaken with $5.0 \mathrm{ml}$ of $2 \% \mathrm{HCl}$ on a steam bath and filtered. To $1.0 \mathrm{~mL}$ of the filtrate was treated with Wagner's Reagent (Iodine in PotassiumIodine solution) and observed for reddish brown precipitate.

\section{(ii). Test for Tannins}

To $1.0 \mathrm{~mL}$ of extract was added an equal volume of bromine water. The formation of a greenish to red precipitate was taken as evidence for presence of condensed tannins.

\section{(iii). Test for Flavonoids}

To $1.0 \mathrm{~mL}$ of extract $1.0 \mathrm{ml}$ of $10 \%$ lead acetate was added. The formation of yellow precipitate is taken precipitate for flavonoids.

\section{(iv). Test for Saponins}

One $\mathrm{mL}$ of extract was boiled with $5.0 \mathrm{ml}$ of distilled water for 5 minutes and decanted while still hot. The filtrate is used for the test. $1.0 \mathrm{ml}$ of the filtrate was diluted with $4.0 \mathrm{ml}$ of distilled water, shaken vigorously and observed on standing for stable froth.

\section{(v). Test for Phenols}

To $1.0 \mathrm{~mL}$ of extract was added $1.0 \mathrm{ml}$ of $10 \%$ ferric chloride. The formation of a greenish-brown or black precipitate or colour is taken as positive for phenolic nucleus.

\subsubsection{Quantitative Determination of the Chemical Constituents}

\section{(i). Alkaloid Determination}

$5 \mathrm{~g}$ of the sample were weighed into a $250 \mathrm{~mL}$ beaker and $200 \mathrm{~mL}$ of $20 \%$ acetic acid in ethanol was added and covered to stand for 4 hours. This was filtered and the extract was concentrated using a water-bath to one quarter of the original volume. Concentrated ammonium hydroxide was added drop 
wise to the extract until the preparation was complete. The whole solution was allowed to settle and the precipitate was collected by filtration and weighed (Harborne, 1973; Obadoni and Ochuko, 2001).

\section{(ii). Tannin Determination}

$500 \mathrm{mg}$ of the sample was weighed into $100 \mathrm{~mL}$ plastic bottle. $50 \mathrm{~mL}$ of distilled water was shaken for one hour in a mechanical shaker. This was filtered into a $50 \mathrm{~mL}$ volumetric flask and made up to the mark. Then $5 \mathrm{~mL}$ of the filtrate was pipette out into a tube and mixed with $3 \mathrm{~mL}$ of $0.1 \mathrm{M} \mathrm{FeCl}_{3}$ in $0.1 \mathrm{~N} \mathrm{HCl}$ and $0.008 \mathrm{M}$ potassium ferrocyanide. The absorbance was measured in a spectrophotometer at $120 \mathrm{~nm}$ wavelengths, within 10 minutes. A blank sample was prepared and the colour also developed and read at the same wavelength. A standard was prepared using tannin acid to get 100 ppm and measured (Van-Burden and Robinson, 1981).

\section{(iii). Flavonoid Determination}

$100 \mathrm{~g}$ of the plant sample were extracted repeatedly with $100 \mathrm{~mL}$ of $80 \%$ aqueous methanol at room temperature. The whole solution was filtered through Whatman filter paper No. $42(125 \mathrm{~mm})$. The filtrate was later transferred into a crucible and evaporated to dryness over a water bath and weighed (Boham and Kocipai, 1994).

\section{(iv). Saponin Determination}

The samples were ground. $20 \mathrm{~g}$ of each plant samples were dispersed in $200 \mathrm{~mL}$ of $20 \%$ ethanol. The suspension was heated over a hot water bath for 4 hours with continuous stirring at about $55^{\circ} \mathrm{C}$. The mixture was filtered and the residue re-extracted with another $200 \mathrm{~mL}$ of $20 \%$ ethanol. The combined extracts were reduced to $40 \mathrm{~mL}$ over water bath at about $90^{\circ} \mathrm{C}$. The concentrate was transferred into a $250 \mathrm{~mL}$ separator funnel and $20 \mathrm{~mL}$ of diethyl ether was added and shaken vigorously. The aqueous layer was recovered while the ether layer was discarded. The purification process was repeated. $60 \mathrm{~mL}$ of n-butanol was added. The combined $\mathrm{n}$ butanol extracts were washed twice with $10 \mathrm{~mL}$ of $5 \%$ aqueous sodium chloride. The remaining solution was heated in a water bath. After evaporation, the samples were dried in the oven to a constant weight. The saponin content was calculated in percentage (Harborne, 1973).

\section{(v). Phenol Determination}

For the extraction of the phenolic component, the fat free sample was boiled with $50 \mathrm{~mL}$ of ether for 15 minutes. $5 \mathrm{~mL}$ of the extract was pipette into a $50 \mathrm{~mL}$ flask, and then $10 \mathrm{~mL}$ of distilled water was added, $2 \mathrm{~mL}$ of ammonium hydroxide solution and $5 \mathrm{~mL}$ of the extract was pipette into a $50 \mathrm{~mL}$ flask, and then $10 \mathrm{~mL}$ of distilled water was added, $2 \mathrm{~mL}$ of ammonium hydroxide solution and $5 \mathrm{~mL}$ of concentration amyl alcohol were also added. The samples were left to react for 30 minutes for colour development. The absorbance of the solution was read using a spectrophotometer at $505 \mathrm{~nm}$ wavelengths (Harborne, 1973; Obadoni and Ochuko, 2001).

\section{Result}

The qualitative analysis of the crude chemical constituents in the Cassia species studied is summarized in Table 3. Alkaloids were very highly present in the leaves of C. alata, $C$. occidentalis and $C$. sieberiana. They were also found to be highly present in the stems, roots and pods of all the investigated species, expect for the pods of $C$. alata, which was very highly present as compared to the leaves.

The leaves, stems, roots and pods of all the investigated species concurrently have tannins highly present in them and saponins very highly present as well. This will go a long way to prove that investigated species are a rich source of saponins, being the most abundant in all the phytochemicals evaluated.

However, flavonoids were very highly present in the stems and roots of $C$. alata and pods of $C$. occidentalis but highly present in the remaining parts of the investigated species as well as in the leaves, stems, roots and pods of $C$. sieberiana.

Results of the phenols show clearly that phenols were concurrently fairly present in the leaves, stems, roots and pods of the studied Cassia species. This reveals that phenols are the least abundant among the phytochemicals investigated.

Table 3. Qualitative analysis of the crude chemical constituents in the studied Cassia species.

\begin{tabular}{|c|c|c|c|c|c|c|}
\hline Taxa & & Alkaloids & Tannins & Flavonoids & Saponins & Phenols \\
\hline \multirow{4}{*}{ C. alata } & Leaf & +++ & ++ & ++ & +++ & + \\
\hline & Stem & ++ & ++ & +++ & +++ & + \\
\hline & Root & ++ & ++ & ++ & +++ & + \\
\hline & Pod & +++ & ++ & +++ & +++ & + \\
\hline \multirow{3}{*}{ C. occidentalis } & Leaf & +++ & ++ & ++ & +++ & + \\
\hline & Stem & ++ & ++ & ++ & +++ & + \\
\hline & Root & ++ & ++ & ++ & +++ & + \\
\hline \multirow{4}{*}{ C. sieberiana } & Leaf & +++ & ++ & ++ & +++ & + \\
\hline & Stem & ++ & ++ & ++ & +++ & + \\
\hline & Root & ++ & ++ & ++ & +++ & + \\
\hline & Pod & ++ & ++ & ++ & +++ & + \\
\hline
\end{tabular}

$(2.00 \%-\sim=$ Very highly present; $1.00-1.99 \%=$ Highly present $; 0.01-0.99 \%=$ Fairly present $)$

$\mathrm{KEY}$

$+++=$ Very highly present

$++=$ Highly present

$+\quad=$ Fairly present 
The quantitative estimation of the percentage crude chemical constituents in Cassia species studied is summarized in Table 4 and Chart 1-5. From the present investigation, all the vegetative and reproductive parts of the studied species were very rich in alkaloids, tannins, flavonoids and saponins in general except for phenols that were fairly abundant. The leaves of $C$. alata ranked the highest percentage of crude alkaloids $(4.06 \pm 0.51 \%)$, tannins $(1.54 \pm 0.01 \%)$, flavonoids $(1.48 \pm 0.14 \%)$, saponins $(4.28 \pm 0.01 \%)$ and phenols $(0.36 \pm 0.00 \%)$ when compared to the leaves of $C$. occidentalis and $C$. sieberiana.

The stems of the Cassia species contained appreciable amount of the crude chemical constituents, which indicatedthat the stem parts of these investigated species are also anabundant source of phytochemicals. Form this result in general; the stems of $C$. alata also recorded the highest percentage of crude alkaloids $(1.46 \pm 0.00 \%)$, tannins $(1.23 \pm 00 \%)$, flavonoids $\quad(2.49 \pm 0.00 \%), \quad$ saponins $(2.36 \pm 0.03 \%)$ and phenols $(0.19 \pm 0.00)$ when compared to other investigated species respectively.

The roots of the studied Cassia species also recorded notable amounts of the crude chemicals. Comparing the roots of the studied species, $C$. alata once again contained the highest percentage of crude alkaloids $(1.62 \pm 0.03 \%)$, tannins $(1.22 \pm 0.0 \%)$, flavonoids $\quad(1.90 \pm 0.03 \%), \quad$ saponins $(2.73 \pm 0.01 \%)$ and phenols $(0.25 \pm 0.0 \%)$. From the investigation, it revealed that the leaves, stems and roots of $C$. alata are very abundant in all phytochemicals investigated.

The pods of these investigated species recorded relatively higher amounts of phytochemicals when compared to the stems and roots of the plants. This indicates that the reproductive structures of these species are also a rich source of crude chemical constituents. From the overall result, the pods of $C$. alata lead in ranking the highest crude alkaloids $(2.70 \pm 0.03 \%)$, flavonoids $(2.68 \pm 0.00 \%)$, saponins (3.94 $\pm 0.04 \%)$ and phenols $(0.28 \pm 0.00 \%)$ while the pods of $C$. occidentalis contained the highest amount of tannin $(1.35 \pm 0.00 \%)$ respectively.

In general, the plants produced high yield alkaloids ranging from $(1.24 \pm 0.06 \%-4.06 \pm 0.51 \%)$, tannins $(1.12 \pm$ $0.01 \%-1.54 \pm 0 \%)$, flavonoids $(1.18 \pm 0.0 \%-2.68 \pm 0 \%)$ and saponins $(2.20 \pm 0.03 \%-4.28 \pm 0.01 \%)$. This could explain why they are recommended for a wide range of treatments.

Table 4. Percentage of the investigated crude phytochemical constituents in the studied Cassia species on dry weight basis.

\begin{tabular}{|c|c|c|c|c|c|c|}
\hline Taxa & & Alkaloids (\%) & Tannins (\%) & Flavonoids (\%) & Saponins(\%) & Phenols (\%) \\
\hline \multirow{4}{*}{ C. alata } & Leaf & $4.06 \pm 0.51$ & $1.54 \pm 0.01$ & $1.48 \pm 0.14$ & $4.28 \pm 0.01$ & $0.36 \pm 0.00$ \\
\hline & Stem & $1.46 \pm 0.00$ & $1.23 \pm 0.00$ & $2.49 \pm 0.10$ & $2.36 \pm 0.03$ & $0.19 \pm 0.00$ \\
\hline & Root & $1.62 \pm 0.03$ & $1.45 \pm 0.01$ & $1.90 \pm 0.03$ & $2.73 \pm 0.01$ & $0.25 \pm 0.00$ \\
\hline & Pod & $2.70 \pm 0.03$ & $1.36 \pm 0.00$ & $2.68 \pm 0.00$ & $3.94 \pm 0.04$ & $0.28 \pm 0.00$ \\
\hline \multirow{2}{*}{ C. occidentalis } & Leaf & $3.50 \pm 0.03$ & $1.38 \pm 0.00$ & $1.24 \pm 0.03$ & $4.17 \pm 0.01$ & $0.30 \pm 0.00$ \\
\hline & Root & $1.45 \pm 0.04$ & $1.29 \pm 0.00$ & $1.30 \pm 0.03$ & $2.48 \pm 0.00$ & $0.19 \pm 0.00$ \\
\hline \multirow{5}{*}{ C.sieberiana } & Pod & $1.31 \pm 0.05$ & $1.48 \pm 0.00$ & $2.51 \pm 0.01$ & $3.79 \pm 0.01$ & $0.25 \pm 0.00$ \\
\hline & Leaf & $3.01 \pm 0.04$ & $1.28 \pm 0.00$ & $1.18 \pm 0.00$ & $3.39 \pm 0.01$ & $0.29 \pm 0.01$ \\
\hline & Stem & $1.44 \pm 0.00$ & $1.12 \pm 0.01$ & $1.74 \pm 0.00$ & $2.20 \pm 0.03$ & $0.15 \pm 0.00$ \\
\hline & Root & $1.24 \pm 0.06$ & $1.35 \pm 0.00$ & $1.24 \pm 0.06$ & $2.62 \pm 0.03$ & $0.19 \pm 0.00$ \\
\hline & Pod & $1.85 \pm 0.01$ & $1.34 \pm 0.00$ & $1.85 \pm 0.10$ & $3.66 \pm 0.00$ & $0.25 \pm 0.00$ \\
\hline
\end{tabular}

Results are mean of five determination dry weight basis \pm standard deviation

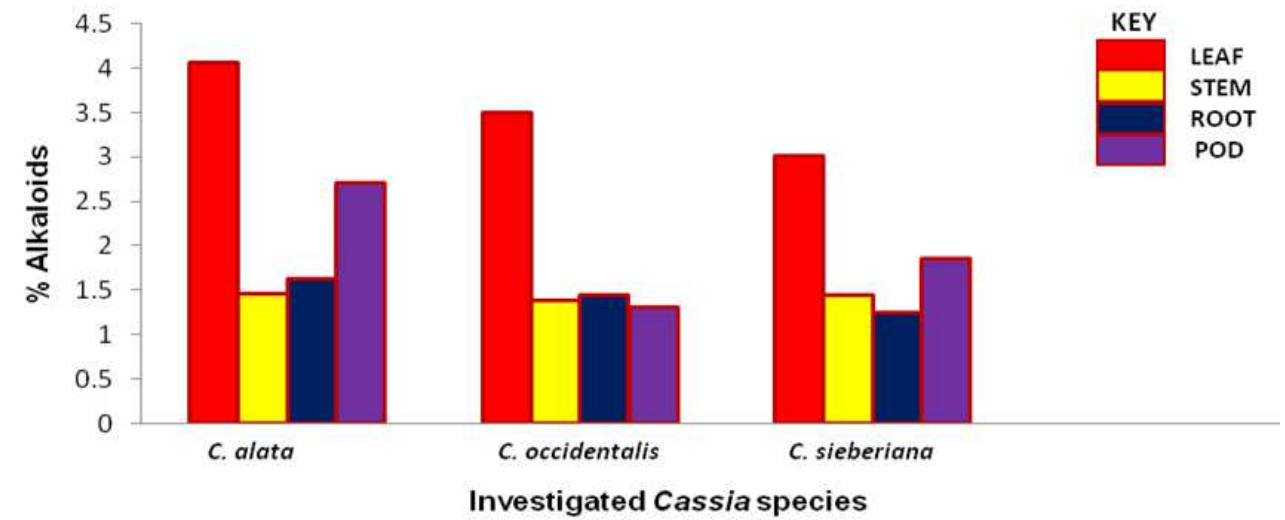

Chart 1. Percentage alkaloids of the screened Cassia species. 


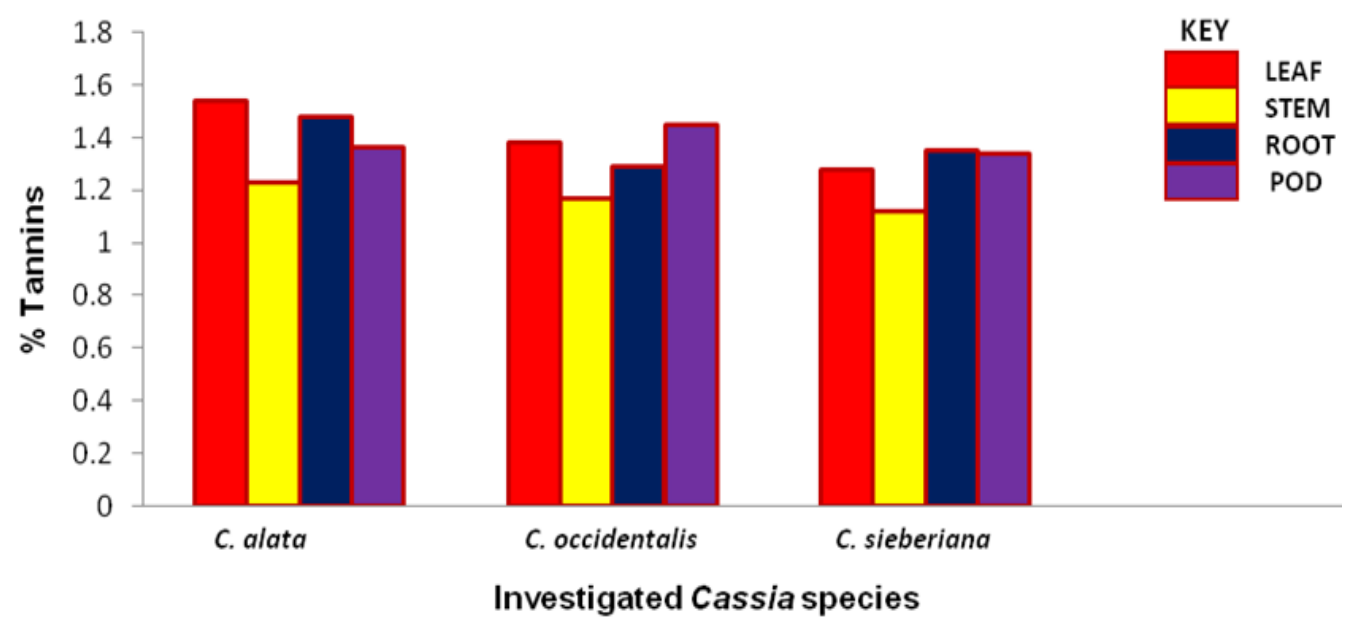

Chart 2. Percentage tannins of the screened Cassia species.

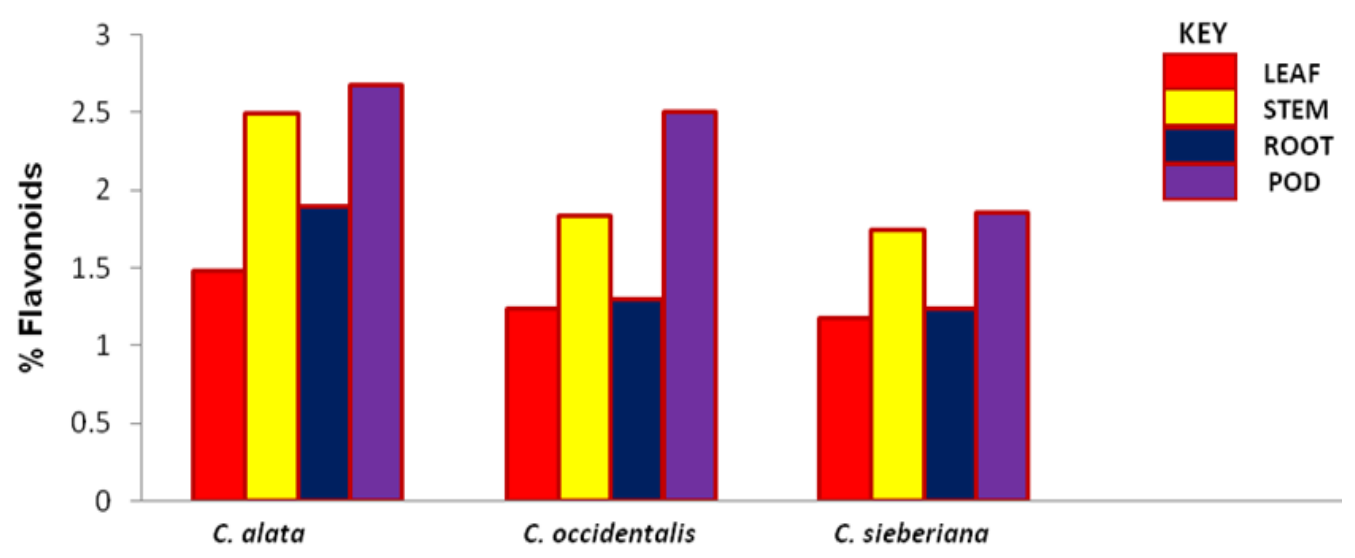

Investigated Cassia species

Chart 3. Percentage flavonoids of the screened Cassia species.

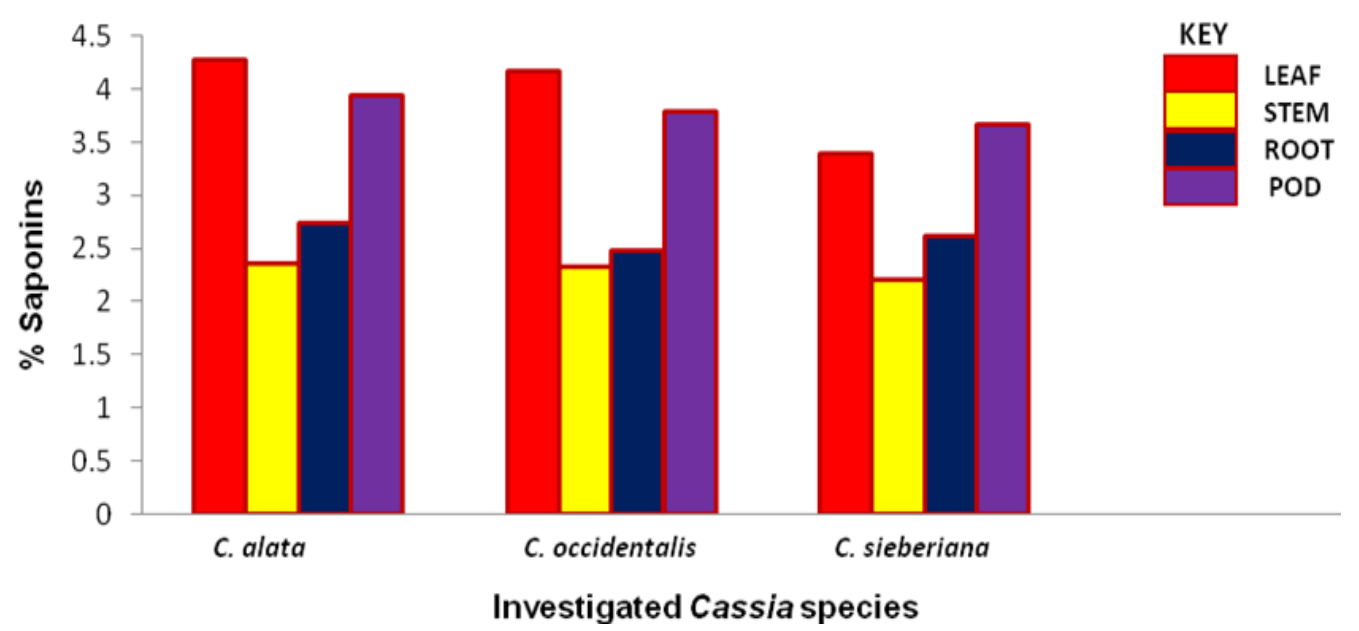

Chart 4. Percentage saponins of the screened Cassia species. 


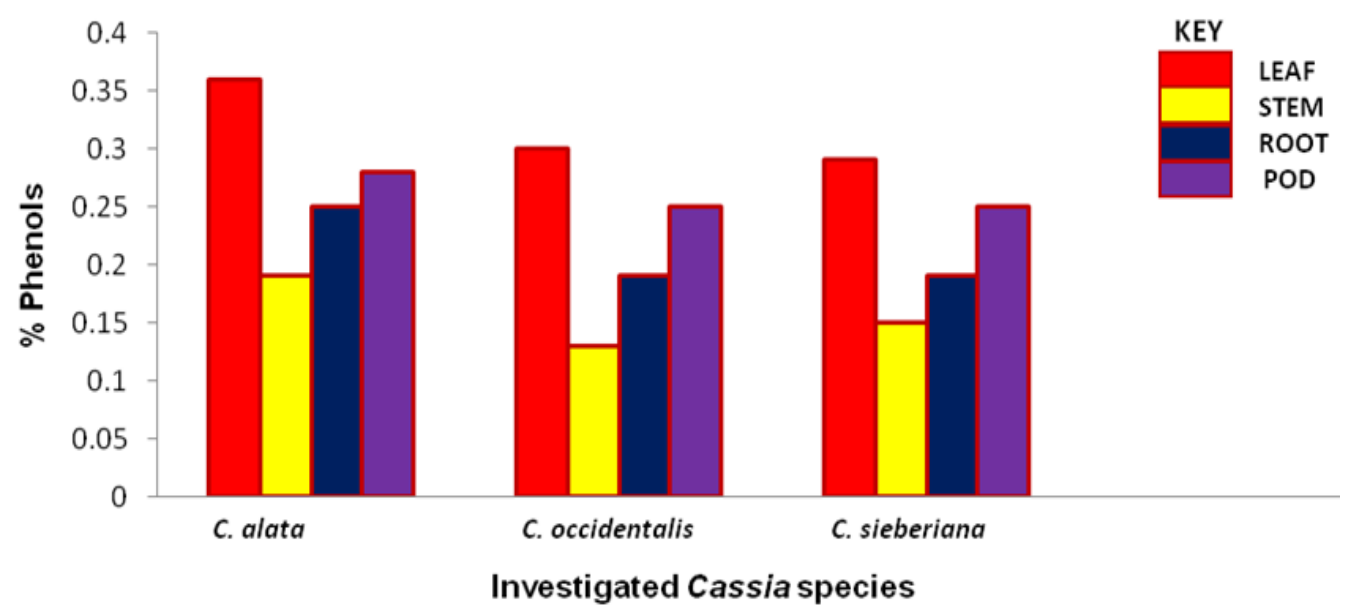

Chart 5. Percentage phenols of the screened Cassia species.

\section{Discussion}

The presence or occurrence of bioactive ingredients and the quantitative estimation of the chemical constituents of the Cassia species studied therefore showed that the vegetative and reproductive parts were rich in alkaloids, flavonoids, saponins and tannins, but little amount of phenols were screened from them, especially in their stem and roots. These biologically active chemical substances known as secondary metabolites in medicinal plants form the foundations of modern prescription drugs (Sofowora, 1993). Cassia species of medicinal importance have been used effectively and extensively in folk medicine for their good therapeutic value (Abo et al., 1999; Elujoba et al., 1989). The presence of these chemical substances in the vegetative and reproductive parts of the three Cassia species studied provides scientific explanations of the long use, recommendations and activities as antimicrobial, antioxidant, antiplasmodic, anti-hormonal, anti-protozoan etc (Sofowora, 1993).

The leaves of $C$. alata had the highest percentage of alkaloids $(4.06 \%)$ seconded by the leaves of $C$. occidentalis $(3.30 \%)$ and then followed by the leaves of $C$. siebariana (3.01\%). Alkaloids have been known to have a powerful effect on properties and animal physiology and are used in medicine especially the steroidal alkaloids and also show considerable pharmacological activity (Edeoga and Eriata, 2001). This explains the reason why boiled roots of $C$. sieberiana are used to treat dropsy and hemorrhoids in Benin Republic (Burkill, 1995). Most of the known functions of alkaloids are related to protection and anti-herbivore defense. In addition, presence of alkaloids in the plants prevents insects and chordates from eating it (Holm et al., 1997). Pure isolated plant alkaloids and their synthetic derivatives are known for their anti-arrhylthmic, anti-cholinergic, anti-tumor, stimulant and sympathomimetric effects (Okwu, 2005).This may be the reason why the leaf decoction of $C$. alata are used in herbal medicine as expectorant in bronchitis and dyspnoea in India, sudorific in China, treatment of hernia, paralysis, headache and convulsion in South America and as an expectorant for cough in Congo Brazzaville, (Idu et al., 2006;
Ross, 2003). It may also explain why the infusions of the leaves of $C$. occidentalis are extensively used in the treatment ofsore throat, cold and flu in Suriname, whooping cough, asthma and hypertension in India, Benin Republic and Suriname respectively (Panda, 2004; Neuwinger, 1996). Furthermore, the aphrodisiac, analgesic and antiprotozoal effects of alkaloids may be the reason why the twigs of $C$. siberiana are used as aphrodisia in Cote d'Ivoire and in the treatment of toothache, sleeping sickness and malaria in Uganda, Benin Republic and Senegal respectively (Arbonnier, 2004).

The leaves of $C$. alata recorded the highest percentage of tannins $(1.54 \%)$ followed by the pods of $C$. occidentalis $(1.48 \%)$. Tannins are known to be organic substances of diverse composition with astringent properties that promote the healing of wounds and inflamed mucous membranes (Frantisek, 1998; Okwu, 2004). The presence of tannin in the leaves of $C$. alata may be the reason why tea made from them are taken as laxatives and also used in the treatment of constipation and intestinal worms in China (Elujoba et al., 1989). Moreover the astringent properties of the leaves and flowers of C. alata can be attributed to the presence of tannins and also the reason they are used as tympanites for poisonous bites and stomach pain in South America (Palanichany and Nagaraj, 1990). Tannins and alkaloids have been documented to show anti-herbivore defense function in plant (Stevens et al., 1995) and this could explain why the leaves of the studied Cassia species are hardly grazed by herbivores. The presence of hydrolysable tannins (Vijayalakshmi et al., 2013) in C. occidentalis and explains why tea madefrom its fresh leaves are recommended for the treatment of gastrointestinal complaints like stomachache, dyspepsia, flatulence and constipation in Panama and India (Warrier, 1994). Similarly, this may also be the reason why the entire parts of $C$. siberiana are used as purgatives in Burkina Faso and in the treatment of stomachache and ulcer in Senegal (Arbonnier, 2004). High levels of tannins in diet have been reported to cause growth suppression. Tannins also have the potential to complex divalent ions such as zinc, iron and copper etc resulting in their unavailability (Okwu, 2004) and have been also reported to form complexes with 
digestive enzymes thus reducing the digestibility of proteins in foods (Amelio, 1999).

The pods of $C$. alata recorded the highest percentage of flavonoids $(2.68 \%)$ followed by the pods of $C$. occidentalis (2.51\%).Although flavonoids are present in reasonable amount in all theinvestigated parts of these Cassia species, the pods and stems are very popular because they have high flavonoid contents. Also, the abundance of flavonoids in the pods over other parts may as well prove the fact that the reproductive parts of plants are a richer source of flavonoids than the vegetative parts because flavonoidsare the pigments found in virtually all plants and are responsible for many of the plant colors that dazzle us with their brilliant shades of yellow, orange, and red in flowers, fruits and seeds (Harborne, 1988). Flavors are related to flavonoids and they promote particular taste to prepared food. This could explain the reason why $C$. alata is used to avert loss of appetite caused by gastro-intestinal problems (Arbonnier, 2004). Flavonoids are known to perform various functions such as anti-oxidant, anti-allergic, anti-viral, anti-carcinogenic, anti-microbial, cardiovascular and hepatoprotective abilities (O'Neil et al., 2000). The appreciable flavonoid contents of $C$. alata is significant enough and therefore supports the pharmacological implications shown by the plant especially in the treatment eczema, ringworm, urticara and rhinitis in Asia and Cote d'Ivoire, and also in the treatment of dysentery, schistomiasis, gonorrhea, heart failure and jaundice in South America (Arbonnier, 2004; Palanichamy and Nagaraj, 1990). Also, the influence of flavonoids can explain the reason why C. occidentalis is considered hepatoprotective and used to treat various stages of hepatitis, liver cirrhosis and various stages of liver failure in India and the roots also used to treat and fortify the liver in Peru and Brazil (Neuwinger, 1996; Warrier, 1994). Furthermore, the presence of flavonoids in $C$. siberiana plays a role in its leaves, roots and pods being used in traditional medicine. In Uganda, this may be the reason why the powder of different parts of the plant is mixed with butter to treat skin diseases and an infusion of the root employed against venereal diseases, diarrhea, dysentery and vomiting (Brenan, 1967). This may also account for its effective usage in Benin Republic where the roots are also boiled in water and used to treat bilharzia, leprosy, blood dysentery and gonorrhea (Burkill, 1995). Flavonoids may act as metal chelators in the cells and selectively reduce or kill cancer cells with high influx of ion (May, 1982). Likewise, Cassia teas containing flavonoids may have health promoting properties.

In all three Cassia species screened, all the plant parts exhibited a high percentage of saponins. The leaves of $C$. alata recorded the highest percentage of saponins (4.28\%) followed by the leaves of $C$. occidentalis (4.17\%). Saponins are often referred to as "natural detergent" because of their foamy nature and they have anti-carcinogenic properties, immune modulation activities and regulation of cell proliferation as well as health benefits such as inhibition of the growth of cancer cell and cholesterol lowering activity (Jimoh and Oladji, 2005).This can explain the reason why the leaf and flower decoction of C. alata is used as mouthwash in stomatitis in Congo Brazzaville (Idu et al., 2006). Saponins serve as natural antibiotics, which helps the body fight infections and microbial invasion (Okwu, 2005). Saponins have been recorded to prevent disease invasion of plants by parasitic fungi and has shown to affect urine, plasma, fecal output and liver cholesterol concentration (Haedi, 1964).This may be attributed to the fact why the entire parts of $C$. alata, C. occidentalis and C. siberiana are commonly used extensively as diuretics in China, India, Peru, Brazil, Suriname, Garbon, Guinea, Senegal and almost all parts of the world these Cassia species are found because of their high contents of saponins (Arbonnier, 2004; Neuwinger, 1996; Panda, 2004; Ross, 2003; Warrier, 1994).The high percentage of saponins in the leaves of the $C$. sieberiana can be attributed why it is an ingredient of a medicine for intestinal worms in Cote d'Ivoire due to the bitter tasting principles associated with saponins (Arbonnier, 2004). Most saponins which readily dissolve in water are poisonous to fish (Titjari, 1989). Also, the presence of saponins may be the reason why the roots and seeds of $C$. sieberiana are used as a fish poison in Cote d'Ivoire (Neuwinger, 2000). The roots and stems are pulverized and mixed in water to create foam which is then poured to the stream to kill or incapacitate the fishes (Neuwinger, 2000). Occurrence of steroidal saponins from various studies indicates their importance and the interest in pharmacy due to their relationship with such compounds such as sex hormones especially in development of the female contraceptive pills (Okwu, 2003). This may be the reason be why boiled leaves of $C$. alata and $C$. occidentalis are taken in Congo Brazzaville to hasten and ease child delivery (Gill, 1992; Neuwinger, 1996). Also, the presence of saponins may be the reason why the decoction of the roots $C$. occidentalis and $C$. siberiana are widely used in Africa in the treatment of women's problems including improving female fertility in Senegal (Neuwinger, 1996) and treating sterility and dysmenorrhea (Neuwinger, 2000) since steroidal structures could serve as potent starting material in the synthesis of these hormones. Saponins are known to make bronchial secretion more liquid, reduce the congestion of the bronchi and acute the congestion of the bronchi and acute coughing (Okwu, 2005). This may be attributed to the fact why the decoction of the leaves of $C$. alata is used for cough and as expectorant in bronchitis and asthma (Esimone, 2008). Other characteristics of saponins include haemolytic activity, cholesterol binding properties and bitterness (Houghton et al., 1996).

Cassia species in general have low phenolic contents when compared to other phytochemicals. The leaves of C. alata not only contained the highest alkaloids, tannins and saponins it also contained the highest percentage of phenols compared to other plants, having $0.36 \%$ followed by the leaves of $C$. occidentalis $(0.30 \%)$ respectively. The presence of phenolic compound in the plant proves that they have anti microbial and anti fungal effect (Huang and Ferraro, 1992). According to Ajose (2005) the fungicide properties of $C$. alata may be associated with presence of phenols. The leaves contain a 
fungicide, chrysophanic acid which is a common ingredient in soap and shampoos and lotions. Chrysaphanol is a form of phenolics (Ajose, 2005). Also, plants that contain phenols could be used as anti inflammatory, immune enhancers and hormone modulators (Okwu and Omodamiro, 2005). Phenols are also known to have the ability to block specific enzymes that cause inflammation and to prevent disease (Okwu, 2004). Phenolic compounds are well known potential phytotoxins and exist as free forms, esters or as glycoside when combined with sugars. Such compounds contribute to the bitter taste, flavours and colour of foods (Manar et al., 2006).

\section{Conclusion}

Current research on herbals has shown that medicinal plants have a potential in today's synthetic era, as numbers of medicines are becoming resistant. The present research on the phytochemicals present in Cassia species studied has not only revealed the medicinal potential of these plants as employed by indigenous people but also their attempt to phytochemically characterize some medicinal plants commonly used in traditional medicine among Nigerians and other parts of globe. However, further studies should be carried out to elucidate the anti- microbial activities of these Cassia species to affirm the claims by traditional healers of the effectiveness of these plants in treating diseases. The various Cassia species studied have been revealed as rich source of phytochemical bases found to be therapeutically active and physiologically important. With this, researchers in medicinal plants will find these plants as potential sources of useful drugs.

\section{References}

[1] Abo, K. A., Lasaki, S. W. and Adeyemi, A. A. (1991). Laxative and antimicrobial properties of Cassia species growing in Ibadan, Nigeria. Journal of Natural Prods Medicine, 3:47-50.

[2] Afolayan, A. J., Aboyade, O. M. and Sofidiya, M. O. (2008). Total phenolic content and free radical scavenging activity of Malva parviflora L.(Malvaceae). Journal of Biological Science, 8:945-949.

[3] Ajose, F. O. A. (2007). Some Nigerian Plants of dermatological importance. International Journal of Dermatology, 46(1): 48-55.

[4] Amelio, S. O. F. (1999) Botanical: A Phytochemical Disk Reference, C.R.C Press Washington D. C.

[5] Arbonnier, M. (2004). Trees, shrubs and lianas of West African dry zones. CIRAD, Margraf Publishers Gmbh, MHHN, Paris, France. pp. 573-575.

[6] Boham, A. B. and Kocipai, A. C. (1994). Flavonoids and condensed tannins from leaves of Hawaiian Vaccinium vaticulum and V. calycinium. Pacific Science, 48: 458-463.

[7] Brenan, J. P. M. (1967). Leguminosae, sub-family Caesalpiniodeae: Flora of Tropical East Africa. CAOGA, London, United Kingdom. p 230.
[8] Burkill, H. M. (1995). The Useful Plants of West Tropical Africa. Vol.3. Families J-L . Royal Botanic Garden, Kew. pp. 605.

[9] Chukwu, T. (2000). Anti-nutritional factors in some selected indigenous species. Unpublished project work, Dept. of Biochemistry, Abia State University, Uturu. pp 8-15.

[10] Dakoro, F. D. (1995). Plant flavonoids: biological molecules for useful exploitation. Aust. J. Plant Physical, 22: 87-99.

[11] Davis, P. H. and Heywood, V. H. (1963). Principles of Angiosperm Taxonomy. Oliver and Boyd, Edinburgh.

[12] Edeoga, H. O. and Eriata, D. O. (2001). Alkaloid, tannin and saponin contents of some medicinal plants. Journal of Medicinal Aromatic Plant Sciences, 23: 344-349.

[13] Edeoga, H. O. and Ikem, C. I. (2001). Tannins, saponins and calcium oxalate crystals from Nigeria species of Boerhavia $\mathrm{L}$. (Nycoaginaceae). South African Journal of Botany, 68: 386388 .

[14] Edeoga, H. O., Okwu, D. E. and Mbaebie, B. O. (2003). Minerals and nutritive values of some Nigeria medicinal plant. J. Med. Aromatic Plant Sci. 25: 1010-1015.

[15] Edeoga, H. O., Okwu, D. E. and Mbaebie, B. O. (2005). Phytochemical constituents of some Nigerian medicinal plants. Afr. J. Biotechnol. 4 (7): 685-688.

[16] Elujoba, A. A., Ajulo, O. O. and Iweibo, G. O. (1989). Chemical and biological analysis of Nigeria Cassia species for laxative activity. Journal of Pharmaceutical and Biomedical Analysis 7(12): 1453-1457.

[17] Esimone, C. (2003). Evaluation of the properties of Cassia species. International Journal of Alternative Medicine, 6(1):59.

[18] Frantisek, S. (1998). The Natural Guide to Medicinal Herbs and Plants. Tiger Books International, PLC, Twickenham, UK. p. 14.

[19] Frodin, G. D. (2004). History and concepts of big plant genera. Taxonomy, 53(3): 753-776.

[20] Gill, L. S. (1992). Ethnomedicinal Uses of Plants in Nigeria. University of Benin Press, Nigeria. p. 276.

[21] Haedi, F. (1964). Die Eingeborenen. Heilpflanzen des unlanga dislike tanganyikeas (osta-erika). In: F. Haerdi, J. Kerharo and J. G. Adam. ArikanshesHeilpflanzen/PlantesMedicinalesAfricanes, Besel. p. 96.

[22] Harborne, J. B. (1973). Textbook of Phytochemical Methods. Chapman and Hall Ltd., London. pp. 49-188.

[23] Harborne, J. B. (1988). Introduction to Ecological Biochemistry 3rd edn. Academic Press London. pp. 10-15.

[24] Heyde, H. (1990). Medicjinplanten in Suriname. (Den dresiwiwiri foe Sranan). "Medicinal Plants in Suriname". Uity Stichting Gizondheidsplante Informaite (SGI) Paramaribo. p. 157.

[25] Holm, L., Del, Y., Holm, E., Panchon, T. and Herberger, T. (1997). World Weeds: National Histories and Distribution. John Wiley and Sons Inc., New York. 
[26] Houghton, P. J., Woldermarian, T. Z., O'Shea, S. and Thyagarajan, S. P. (1996). Two securinega type alkaloids from Phyllanthus amarus. Phytochemistry, 43: 715-717.

[27] Huang, M. T. and Ferraro, T. (1992). Phenolic compounds in food and cancer prevention in phenolic compounds in food in the effects of health II. In: Huang, M. T., H.O.C.T., C. T. (Eds) Acs Symposium Series 507; American Chemical Society, Washington D.C. pp. 8-34.

[28] Hutchinson, J. and Dalziel, M. D. (1963) Flora of West Tropical Africa, vol. 2. Crown Agents, London, UK.

[29] Idu, M., Oronsaye, F. E., Igeleke, C. L. and Omonigho S.E. (2006). Prelimianary Investigation on the Phytochemistry and Antimicrobial Activity of Cassia alata leaves. Journal of Applied Sciences, 6(11): 2481-2486.

[30] Igile, G. O., Olezzek, W., Jurzysta, M., Burda, S. (1994). Flavonoids from Vernonia amygdalina and their anti oxidant activities. Journal of Agriculture, Food and Chemistry, 42: 2445-2446.

[31] Jimoh, F. O. and Oladji, A. T. (2005). Preliminary studies on Pilostig mathonningii seed: proximate analysis, medicinal composition and phytochemical screening. African Journal of Biotechnology, 4(12): 1439-1442.

[32] Kapur, B. M. and Atal, C. K. (1982). Cultivation and Utilization of Medical Plants. Regional Research Laboratory Council of Scientific \& Industrial Research, Jammu-Tawi, India. p. 877.

[33] Manar, A., Al-Charachetechi, F. and Modallel, N. (2006). Biological activity and anti mutagenicity of water soluble phytotoxins from Artemisia herba Alba. Pakistan J. Biol Sci., 9(9): $1974-1978$.

[34] May, A. I. (1982). Surinaams Kruidenboek. Sranan Oso Drei. "Surinameses Book of Herbs" UitgeeverjiVaco, ParamariboSuriname. p. 80.

[35] Neuwinger, H. D. (1996). African Ethnobotany: Poisons and Drugs: Chemistry, Pharmacology, Toxicology; Weinheim: Chapman and Hall, London. Pp. 287- 293.

[36] Neuwinger, H. D. (2000). African Traditional Medicine: A Dictionary of Plant Use and Applications with Supplement: Search System for Diseases. Medpharm Scientific Publishers, California, USA. pp. 589-593.

[37] O’Neil, L., Kim-Standage, W. S., Hughes, G. B. and Murray, K. B. (2000). In: Watson, R. R. (2000). Ed. Vegetables, Fruits and Herbs in Health Promotion, C. R. C. Press, USA.

[38] Obadoni, B. O. and Ochuko, P. O. (2001). Phytochemical studies and comparative efficacy of the crude extracts of some homeostatic plants in Edo and Delta States of Nigeria. Global J. of Pure and Applied Sciences, 8: 203-208.

[39] Okwu, D. E. (2003). The potentials of Ocimum gratissimum, Pengularia extrensa and Tetrapleura tetraptera as spice and flavouring agents. NigAgric J., 34:143-148.

[40] Okwu, D. E. (2004). Phytochemicals and vitamin contents of indigenous species of South Eastern Nigeria. Journal of Sustainable Agriculture and Environment, 6: 30-37.

[41] Okwu, D. E. (2005) Phytochemicals, vitamins and mineral contents of two Nigerian medicinal plants. International
Journal of Molecular Medicine and Advanced Sciences, 1: $375-381$.

[42] Okwu, D. E. and Omodamino, O. D. (2005). Effects of hexane extract and phytochemical content of Xylopia aethiopica and Ocimum gratissimum on uterus of guinea pig. Bio. Research, 3: 40-44.

[43] Omaye, S. T. (2004). Food and Nutritional Toxicology. C. R. S. Press, USA. pp. 184-215.

[44] Palanichamy, S. and Nagarajan, S. (1990). Antifungal activity of Cassia alata leaf extract. Journal of Ethnopharmacology, 29:337-340.

[45] Panda, H. (2004). Handbook on Medicinal Herbs with Uses. Asia Pacific Business Press, New-Delhi. p. 287.

[46] Perry, M. L. (1980) Medicinal Plants of East and Southeast Asia: Attributes, Properties and Uses. MIT Press, Massachusetts, USA. p. 128.

[47] Robber, J. M. and Speedie, T. V. (1996). Pharmacognosy, Pharmacobiotechnology. Williams and Wilkins, Baltimore. pp $1-14$.

[48] Ross, L. A. (2003). Medicinal Plants of the World: Chemical Constituents, Traditional and Modern Uses. vol. 2, 2nd edn. Humana Press, Totowa, New-Jersey, USA. p 489.

[49] Schrire, B. A., Lavin, M. and Lewis, G. P. (2005). "Global distribution patterns of the Leguminosae: Insights from recent phylogenies" In: I. Friis and H. Basley (Eds), Plant diversity and complexity patterns: Local, regional and global dimension. Biol. Skr., 55:375-38

[50] Sofawara, A. (1993). Medicinal Plant and Traditional Medicine in Africa. Spectrum Books Ltd. Ibadan, Nigeria. p. 289.

[51] Stevens, P. F. (2001). Angiosperm Phylogeny. Website Version. www. mobot. org.

[52] Steven, J. F., Hart, T., Han, R. C., Van-Elema, E. T., Uander, E. M., Wilderboer, M. Zwaving, J. H. (1995). Distribution of alkaloids, tannins in the Clussiaceae. Biochem. Syst. Ecol., 23: 257-276.

[53] Trease, G. E. and Evans, W. C. (1989). Pharmacognosy II. 2nd edn. BraillierTiridel and Macmillian Publisher, London.

[54] Titjari, Z. K. (1989). Fraunivi-encyclopedia Foe da NatoeraPresi - Fasi. Gezinsleruiden bock van de Natwurgenesivijzen. Natwurgenesivijzenuit her Zonnige Suriname. "Family Herb Book of Cures, Natural Cures of Sunny Suriname" Amsterdan. p. 419.

[55] Van-Burden, T. P. and Robinson, W. B. (1981) Formation of complexes between protein and tannic acid. J. Agric. Food Chem. 11: 77 .

[56] Vijayalakshmi, S., Ranjitha, J., Devi Rajeswari, V. and Bhagyalakshmi, M. (2013). Pharmacological Profile of Cassia occidentalis L. Review. Int. J. Pharm. And Pharm Sci. 5(3): 29.

[57] Warrier, P. K. (1994). Indian Medicinal Plants: A Compendium of 500 Species: vol. 2. Orient Longmans Chennai, India. p. 19.

[58] Zhu, M., Phillipson, T. D., Greengrass, P. M., Bowney, J. and Cai, T. (1997). Plant polyphenols: biological active compounds of non-selective binders to protein. Phytochemistry, 44: 441-447. 